\title{
The Thoughts and Countermeasures of Ideological and Political Work in College and Universities in the Form of Chinese-foreign Cooperatively-run Schools
}

\author{
Liu Juan \\ Yunnan Agricultural University, Kunming, Yunnan, China, 650201
}

\begin{abstract}
Keywords: Sino-foreign cooperative education; Special mode of schooling; Ideological and political work

Abstract: Chinese-foreign schooling is a special mode of running a school. In China, it was established in the 1990s. The purpose is to introduce foreign advanced educational experience and talents through Chinese-foreign cooperation in running schools, so as to train more talents for the socialist construction. However, during Chinese-foreign cooperation in running school, the ideological and political work under Chinese-foreign cooperatively-run schools facing serious impacts and challenges due to problems such as school model and value. Under the present conditions, it is necessary to strengthen ideological and political work to provide some help for the ideological and political work under Sino-foreign cooperation. In this case, the current state of the university of China and the state of the university, and then I suggest to strengthen the leadership of the party, so as to provide a lesson for the current Chinese and foreign cooperation.
\end{abstract}

With the opening of the communist party of China (CPC), it has put forward new requirements for the ideological and political work of the students in this school, which is to cultivate a new generation of talents with strong socialist ideals [1-3]. Therefore, under the new situation, strengthening the ideological and political work of colleges and universities under the form of Chinese-foreign cooperation has become an important subject in the work of education. To this, this paper combined with the current problems existing in the Chinese and foreign education mode of ideological and political work, combined with practical work, put forward the related countermeasure and the suggestion, in order to advance the ideological and political work in colleges and universities, to cultivate more firm socialist successor.

\section{The origin and status of a Chinese-American partnership}

The Chinese-foreign Cooperative-school model has been developed in the 1990s. After nearly two decades of development, Sino-foreign cooperative education has achieved a lot. Since the beginning of the 21 st century, the world economy has been developing at a high speed and the world pattern is changing. Under such historical background, world integration has become an inevitable trend of The Times. Education, as part of world integration, is bound to be more closely 
linked with the development of The Times. As early as more than 30 years ago an American educator put forward [4], under the new era should people in a radical idea to look at higher education, the idea is the internationalization of higher education, is the Chinese-foreign cooperation in running schools. The core of this model is "foreign education institutions and some education institutions in China or local governments in cooperation with schools, and the students are mainly students who are trained by education institutions."

After nearly two decades of development, China has nearly 1,000 Chinese-foreign cooperative schools, all over the country. Chinese-foreign cooperative education mode has become a new way of cooperation and exchange between Chinese and foreign education in the new era, and it is a new way to cultivate socialist talents. However, in the course of Chinese-foreign cooperatively-run schools, there are many problems, especially the ideological and political work of universities.

\section{Problems arising in ideological and political work under the form of Chinese-foreign cooperation}

Due to different social systems and different social values, many problems in the ideological and political work of college students have appeared in the process of Chinese-foreign cooperation in running schools [5-7], which cannot be ignored.

\subsection{Lack of motivation and spirit of hardship}

Chinese-foreign cooperation in running schools and colleges and universities domestic biggest different is the student's family background, Chinese-foreign cooperation in running schools mode of university students' most of the family rich, no employment pressure, so under such circumstances, shortage of students' learning motivation. They think that their parents sent them to Chinese-foreign cooperatively-run schools to make their own plating, and the family has solved the work problem naturally. There are also some students who are rich in the second generation. Parents want their children to learn more knowledge, improve their learning skills, and then inherit the family business. In this case, the students have the psychology of opportunism, and they don't realize the importance of study.

\subsection{The students' values are seriously westernized}

In Chinese-foreign cooperation in running schools in colleges and universities, the increase in the number of exchange students both at home and abroad, many lessons by foreign teachers, even in domestic teach, because of the need to continue to study abroad, so some lessons by foreign teachers. In the course of teaching, these teachers infiltrate the western cultural ideas and values, which subtly influence the thoughts of college students. Chinese-foreign cooperation in running schools in life mode of the Chinese students and western students exchange frequently, because they are very high level of consumption, will these invisible consumption patterns into the Chinese students, not only increase the burden of the Chinese students, it also increased the materialism of Chinese students.

\subsection{The students' comprehensive quality is reduced and the psychological problems are frequent}

Many parents choose Chinese-foreign cooperation to run schools. The purpose is to improve the comprehensive quality of their children, improve their comprehensive ability, enhance their awareness and broaden their horizons through the teaching model of Sino-foreign cooperation. 
Because the child's family background is pretty good, many are only children, in the home is in the greenhouse flowers, family too care and dote on, students lack experience in terms of self-management, dealing with problems, have individual character. In this case, the strength of the student delicate, are self-centered, can't afford to setbacks and difficulties, but the setbacks and difficulties, at a loss, a lot of students suffer from serious mental illness, some students even commit suicide.

\subsection{Weak self-confidence and great psychological pressure}

Most of the students entering Chinese-foreign cooperatively-run schools are well-off families, but their academic performance is not very good, and their scores in the college entrance examination are equally unsatisfactory. The parents of these students want their children to go to Chinese-foreign cooperative schools after the college entrance examination, because the admission scores of these schools are low, but they are all accepted by the two students. After the students enter the school, because of the high school grades are not ideal, so after entering school, a serious shortage of self-confidence, inferiority complex is serious, think that I am poor school performance, and the gap is too big to get into a students. The students on the one hand, hope that through Chinese-foreign cooperation in running schools in colleges and universities teaching conditions, teacher resources, change their poor performance in the original, on the one hand, due to poor basis for will keep up with learning rhythm, often left behind, greatly reduces the interest in learning, psychological pressure, self-denial, often without learning motivation.

\subsection{Over-emphasis on ego and poor teamwork spirit}

In Chinese-foreign cooperation in running schools in colleges and universities school students, family conditions are good, plus the usual communicate with foreign teachers and students, these students too much emphasis on the self, overemphasis on self-feeling, ignoring the exchange and cooperation between classmates. The way they may be associated with the environment of his life since childhood, bossy, selfish and self-centered, such behavior is not conducive to communication and cooperation between classmates, is not conducive to teamwork, more detrimental to the environment in Chinese-foreign cooperation in running schools colleges and universities.

\subsection{The thought is too avant-garde and lacks patriotic enthusiasm}

Due to the Chinese-foreign cooperation in running schools college students most of the family life rich, and more contact with foreign teachers and students, the student's thought is very halfback, often do some incredible things in life. Such an environment created for Chinese-foreign cooperation in running schools students state the concept of relatively weak, indifference, even in such cases, some students even do something bad for the country.

\section{Ideas and Countermeasures for ideological and political work in Colleges and Universities under the form of Sino-foreign cooperation in running schools}

\subsection{Strengthen party construction and adhere to the leadership of the party}

Sino-foreign cooperation in running schools is a special way of China's higher education. It is also the main front for cultural exchanges between China and foreign countries, and the frontier of China's foreign exchange. Under such circumstances, the ideas of Chinese and foreign cooperative universities are diversified. In this case, we must adhere to the mode of running a school led by the 
party and strengthen the party's leadership as the fundamental guarantee for the cooperation of Chinese and foreign cooperation in running a school. In the work of Party building, the party organization construction should be penetrated into various schools in accordance with the different conditions between universities and Colleges under the mode of Chinese and foreign cooperation, to ensure the synchronous development of Party construction work and school construction, to set up party groups in time, and to adjust and optimize the party organization in time in accordance with the actual conditions of running a school so as to prevent the emergence of a big cart Phenomenon. Enqiao Jiang, deputy director of the two bureau of the Central Organization Department, said: "in accordance with the principle of who launch for and who is responsible for that, it is clear that the Party committee of the Chinese University is the main body responsible for the cooperative education." Jinhui Lin, the director of the research center of Chinese and foreign cooperation in running school of Xiamen University, said that strengthening the work of Party building should work hard on the construction of teachers, and the ideological and political educators in Colleges and universities should firstly strengthen their own position and improve their ideological and political level. He believes that "if Sino-foreign cooperation in running schools is a special area for the reform of higher education, then there will be no special zone for the leadership of the party." The purpose of [9] is to keep the ideology of colleges and Universities under the form of Sino-foreign cooperation in running schools to remain pure and keep the correct direction, so that it will not go astray and go wrong.

\subsection{Use the network to carry out publicity and education, and take the mode of ideological education combined with investigation and guidance}

The modern society is an era of information network. After a comprehensive understanding of the ideological situation of college students in the form of Chinese and foreign cooperation in running a school, according to the ideological situation and actual state of the students, through the field visit in addition to the network thought education, this kind of education will have the effect of half work. Modern university students will use the network, whether it is mobile phone and computer, the time of college students surfing the Internet accounts for more than half of the students' study. In this case, the best way to use the network to carry out ideological education is the best way. Colleges and universities in the form of Chinese and foreign cooperation can make use of various modes such as online questionnaire and online interaction to grasp the ideological trends of college students in time and to master the students' ideological situation in the first time. In this way, the ideological dynamics of college students can be mastered most accurately, and the best solutions can be found, the students are classified and the education of the store is carried out. Online education can reduce the psychological burden of students, let college students open their heart to speak their own ideological situation, from understanding to solving, and then to education can achieve equal communication, honest and honest, and carry on the ideological education.

\subsection{Improve the ideological and political quality of teachers}

In Sino-foreign cooperation in running schools, teachers and students get along with each other every day, and the impact on students can be imagined. Teachers' influence on students can be said to be invisible and imperceptible. No matter the way of behavior and values, teachers have great influence on the students, so the key to the ideological and political work of Chinese and foreign cooperative colleges and universities is the teacher. Under such circumstances, the Chinese side should be strict with teachers and strengthen the education of Marx doctrine and materialism theory, especially the theoretical quality of foreign teachers. Because their values and ideas are incompatible with Marx's doctrine, they should guide the foreign teachers in the ordinary teaching 
and try to improve the teachers. In particular, the ideological and moral qualities of the young teachers let them spread positive energy in teaching, reduce the spread of western liberalism, and make them the communicators and passers-by of science and technology.

\subsection{Strengthen the innovation of ideological and political education mode under the Internet}

The ideological and political education into the network is on the basis of making full use of modern information technology. In view of the psychological state and cognitive characteristics of current college students, through the construction of related network and the production, dissemination and control of network ideological and political education information, the virtual activities of the two-way interaction between college counselors and college students are realized, so as to cultivate the virtual activities of the two-way interaction between college counselors and college students. The netizens of contemporary college students form ideas, moral cultivation and behavior norms that are in line with the trend of the times and social needs. With the development of social networks, network teaching has become a new medium and new form of teaching in Colleges and universities. In this case, we can use the network as the medium to carry out the ideal and belief education and patriotism through the online party school, the online school, the online collection, the online award competition, and constantly enhance the pertinence and artistry, and constantly improve the clicking rate and influence. At the same time, Chinese and foreign cooperative school students should be encouraged to establish electronic publications or public numbers to publicize patriotic deeds and attract more student audience through this form, so that students can learn patriotism in the network.

\subsection{Strengthen the theoretical construction of colleges and universities}

Both ideological and political work in Chinese universities and ideological and political work in Colleges and Universities under the form of Sino-foreign cooperation in running schools are inseparable from correct theoretical guidance. This theory must be a forward-looking and regular theory, and only in this way can we point out a correct direction for the ideological and political work of colleges and universities under the form of Chinese and foreign cooperation. In the direction of the development of colleges and universities, we should adhere to the fundamental characteristics of "Chinese characteristics", [10], adhere to the fundamental direction of "Lide tree people", adhere to the guiding principle of "people-oriented", adhere to the development model of "deepening education", and strive for the basic and key issues of Chinese and foreign cooperation in running schools, so that all teaching staff can actively participate in teaching work.

\subsection{The combination of self-education and school education}

Chinese foreign cooperation in running schools is a critical period to carry out ideological and political education. At this time, the school should actively organize the students to carry out patriotic education, such as the 54 Youth Festival, the Nanjing massacre day, the victory day of the Anti Japanese War and other patriotic activities, so that these activities truly infect the students and stimulate their patriotic enthusiasm. After these activities are finished, let students write their experiences, write what they see and hear, and find out their own shortcomings and advantages.

Zeng $\mathrm{Zi}$ said that we can make a new step of Ideological and political work in the form of Chinese and foreign cooperation only through the combination of school education and self-education. 


\section{Conclusion}

In the form of Chinese and foreign cooperation in running schools, the ideological and political work of colleges and universities must be done well. This work is about the future of university education in China and foreign countries. Only through the correct way of education, taking effective measures, and strengthening the ideological and political work of colleges and universities in the form of Chinese and foreign cooperation in running schools, can this work be promoted. to a new height.

\section{References}

[1] Zhongming Liao, Lingqun Liu, Wei Lai. The exploration and practice of the management of Chinese and foreign cooperative school students in Higher Vocational Colleges -- Taking the international exchange class of Jiangxi Environmental Engineering Vocational College as an example, [J]. technology information, 2013 (02): 281-282.

[2] Yongting Zheng. Some thoughts on the whole process of Ideological and political work in Colleges and Universities - learning from general secretary Xi Jinping's speech at the National College of Ideological and political work, [J]. ideological and theoretical education, 2017 (01): 4-9.

[3] Shuanghao She. New changes, new perspectives and new trends in Ideological and political work in Colleges and universities [J]. Youth Development Forum, 2017,27 (01): 16-23.

[4] Jidong Zhu. The problems existing in the ideological and political work of colleges and universities in the new period and their Countermeasures -- the important speech of Xi Jinping in the National College of Ideological and political work, the spirit of the party and the government research on the party and government, 2017 (02): 28-39.

[5] Juhua Hu. On the optimization of cultural ecology in Ideological and political work in Colleges and universities; analysis of [J]. Marx doctrine; 2017 (04): 141-148.

[6] Shoucheng Xie. Lead the ideological and political work in Colleges and universities with scientific thinking to innovate and develop [J]. Chinese University Social Sciences, 2017 (02): 4-10+156.

[7] Shuanghao She. Taking the contemporary Chinese Marx doctrine as the guidance to run the socialist university with Chinese characteristics well - learning from general secretary Xi Jinping's speech at the National College of Ideological and political work ([J].), 2017 (10): 37-45.

[8] Jihua Xie, Hongjie Fa, Feikai Huang. Using big data to innovate ideological and political work in Colleges and universities. A preliminary study of [J]. ideological and theoretical education guide, 2015 (07): 137-140.

[9] Li Li. Analysis and Countermeasures of the ideological and political work in Colleges and universities from the media age [J]. education exploration, 2013 (11): 124-125.

[10] Lianfu Lv. Strengthening and improving ideological and political work in Colleges and Universities under the form of Sino-foreign cooperation in running schools [J]. Journal of Ningbo University (Educational Science Edition), 2005 (02): $92-94$.

Liu Juan, Female, Honghe state, Yuannan Province, master lecturer research direction: higher education 